adyocated the setting up of central agencies to simplify procedure (a suggestion also recommended in Great Britain), especially in cases where speed is essential. Prof. E. Reimer, another authority on the subject, was unable to attend.

To some extent the problems attached to the use of microfilms in Germany have been similar to those in Great Britain, though where the British often hesitate, the Germans have made quick decisions, and a variety of answers now strive for co-ordination. The requirements of ad hoc copying are distinct from those which govern organised reproduction; but any solution must keep within the provisions of a restricted economy. There seems to be scope for transparent as well as opaque material, flat shapes as well as long lengths, celluloid and 'Cellophane', high- and low-reduction ratio, microfilm with or without perforations, microcards, miniature prints, and so on, with the limitations mainly imposed by dearth of machinery.

To keep in check and, if possible, to standardize the existing variety of experimental methods, were among the aims the Conference set out to achieve. Apparatus, material and samples of work done were on view, to give practical backing to a number of technical points. It was, however, realized in the course of discussions that account must be taken of corresponding efforts carried on outside Germany, if international co-operation is to be restored, this being the other objective foremost in the minds of those who organised the Conference. The presence of foreign guests, including Mr. Donker Duyvis, general secretary of the International Federation for Documentation, to whom the Deutsche Gesellschaft für Dokumentation has now applied for re-affiliation, was welcomed as a hopeful sign in this direction.

L. Моноцу

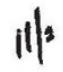

\section{PHYSICS IN GERMANY}

A DISCUSSION about the claims of technical physics to 10 regarded as a subject in its own right begap a e the International Congress for the Trainin of ringineers in Darmstadt in 1947, and has been chlyiod on in Physikalische Blaetter (No. 8, 253; $197 \%$. No. 1,$16 ; 1948$. No. 3,$110 ; 1948)$, and is stidgoing on.

Prof. C. Ramsauer, an eminent 'technical physicist' himself, founder and director of the A.E.G. Research Station, is emphatically opposed to the idea of technical physics as a special subject, although formerly there was a society devoted to it of which Prof. Ramsauer was president. Prof. Ramsauer states that during the First World War, both industrial and Government authorities were surprised at the superiority of 'pure physicists' over engineers in the solution of technical problems. Soon it was generally recognized that where new ground is to be tilled, it is not the routine of the engineer but the comprehensive grasp of fundamentals that assures success. The teaching of engineers, he believes, should be the same as that of all other physicists, supplemented in the advanced stages by technical courses not occupying more than one third of the total time, this total excluding mathematics and chemistry but including physical chemistry. The most grievous injury inflicted on German science by the Nazi regime was the substitution of the diploma examination for the doctor's dissertation; an examination deals with present knowledge whereas the thesis teaches the student to explore the unknown.

The opposite view has been advocated by Prof. Vieweg. He maintains that 'technical physics' must be a separate subject from the start. The technical physicist is a liaison officer between physics and engineering. Prof. Vieweg believes there should be mutual fertilization, and the term 'technical physics' expresses better than 'applied physics' this reciprocity. The task of technical physics is to loosen up and prepare the ground for technical development.

Prof. Ramsauer, after quoting replies to a questionnaire, most of which share his view, invites university authorities and industrial leaders to express their opinion about some concrete proposals which he sets forth. These include the demands that the term 'technical physics' should be completely dropped and that, as before, the doctor's degree should be the natural goal of every physicist's training. He calls this a matter of life and death for German science.

The Deutsche Physikalische Gesellschaft in der britischen Zone has declared at its board meeting of September 8, 1948, that it adopts the views of Prof. Ramsauer. It is of the opinion that there is no 'technical' physics, but only physics; technical physics is nothing but the application of pure physics to technical problems, and no special syllabus is required for such purposes. The Society considers that the introduction to technical mechanics and into electrotechnics should be taught at universities. Special technical problems ought to be dealt with in accordance with local conditions; however, they must not endanger the thoroughness of the general scientific education.

The obligatory doctor's dissertation is regarded as most important; its abolition during the Nazi regime was a great misfortune. The Society is most anxious that the 'diploma examination' should again be replaced by the 'doctorate examination'. In the meantime, it requests all authorities and firms to give preference to candidates who have obtained the doctor's degree. Gratification was expressed at the board meeting that its views are approved by the most important industrial firms.

\section{FORTHCOMING EVENTS}

(Meetings marked with an asterisk * are open to the public)

Saturday, February 19

Institute of PHYSICs, INDUSTRIAL RADIOLOGY GROUP (at $47 \mathrm{Bel}$ grave Square, Kondon, S.W.1), at 10 a.m. -Discussion on "Layout and Plaming fondiographic Inspection".

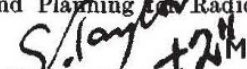
Monday, February 21

UNIVERsitr of LONDON (at King's College, Strand, London, W.C.2), at 5.30 p.m.-Dr. H. G. Thornton, F.R.S.: "The Ecology of Bacteria with Especial Reference to Soil"." (Further Lectures on February 28 and March 14.)

ROYAL SOCLETY of ARTS (at John Adam Street, Adelphi, London, W.C.2), at 8 p.m.-Dr. W. H. J. Vernon : "The Corrosion of Metals". (Cantor Lectures.) (Further Lecture on February 28.)

ROYAL GEOGRAPHICAL SOOIETX (joint meeting with the ROYAI ROYAL GEOGRAPHICAL SOOIETY (joint meeting with the ROYAI
SocrerY, at Kensington Gore, London, S.W.7), at 8.15 p.m.- Prof. Hans Pettersson: "Exploring the Ocean Bed".

\section{Tuesday, February 22}

ROYAL ANTHROPOLOGICAL INSTITUTE (at 21 Bedford Square, London, W.C.1), at 5 p.m.-Mr. W. G. Archer: "Primitive Indian Pottery",

INSTITUTE of SOcroLiogr (at the Royal Institute of British ArchiINSTITUTE of SOcrologr (at the Royal Institute of British Archi-
tects, Portland Place, London, W.1), at $5.30 \mathrm{p}$.m.-Dr. G. Scott-
Williamson: "The Family as a Basis of Society". Williamson: "The Family as a Basis of Society".

InSTITUTION OF ELECTRICAL ENGINEERS, MEASUREMENTS SECTION (at Savoy Place, Victoria Embankment, London, W.C.2), at 5.30 p.m -Discussion on "Automatic Precision Instruments" (to be opened by Dr. A. T. Starr). 